\title{
Prevalence of Campylobacter species in ground water in Sokoto, Sokoto state, Nigeria
}

\author{
Agatha N. Ugboma, Muhammed D. Salihu, Abdullahi A. Magaji and Mikail B. Abubakar \\ Usmanu Danfodiyo University, Sokoto, Sokoto State, Nigeria. \\ Corresponding author: Agatha N. Ugboma, email:dr.agathaugboma@gmail.com \\ Received: 02-08-2012, Accepted: 28-09-2012, Published online: 25-02-2013
}

\begin{abstract}
How to cite this article:
Ugboma AN, Salihu MD, Magaji AA and AbubakarMB (2013) Prevalence of Campylobacter species in ground water in Sokoto, Sokoto state, Nigeria, Vet. World 6(6): 285-287, doi: 10.5455/vetworld.2013.285-287
\end{abstract}

\begin{abstract}
Aim: The present study was conducted to determine the presence and prevalence of Campylobacter species in ground water in Sokoto, Sokoto State.

Materials and Methods: The prevalence of Campylobacter species was determined by collecting a total of 74 water samples from wells in Sokoto over a period of four months from May to August 2011 and analyzed using cultural isolation techniques and biochemical characterization.

Results: Totally 39 (52.70\%) water samples were Campylobacter positive. The species identified were Campylobacter jejuni 23 (58.97\%), Campylobacter coli 11 (28.21\%) and Campylobacter hyointestinalis 5 (12.82\%).

Conclusion: Based on this study, the isolation of Campylobacter species from ground water (wells) in this study is of serious public health importance as untreated water has been implicated as the cause of sporadic infections and outbreaks of Campylobacteriosis worldwide.
\end{abstract}

Keywords: Campylobacter, prevalence, public health, Sokoto, water, well.

\section{I ntroduction}

Thermophilic Campylobacters are among the most common bacteria that cause acute human and animal gastroenteritis worldwide [1-4]. Campylobacteriosis is an infectious disease caused by the gram negative bacteria Campylobacter [5-7]. Apart from contaminated food and drinking water, direct contact with carrier animals was found to be a possible source of infection for Campylobacter [8-12]. Outbreaks of Campylobacteriosis are often associated with consumption of unpasteurized milk $[4,13]$ or untreated water [4,13-15]. Campylobacteriosis is characterized by diarrhea, abdominal pain, malaise, fever, nausea and vomiting $[4,6,16]$. Well water is one of the major sources of drinking water in Sokoto metropolis. it's usage by humans and animals is due to insufficient supply of pipe-borne water and poor management of water in the metropolis [17]. Campylobacter may be found in water sources such as wells that have been contaminated with feces from infected humans or animals. Most Human or animal waste can enter the water through different routes including sewage systems that are not working properly, polluted storm water runoff and agricultural runoff [7]. The rate of Campylobacter infections worldwide has been increasing with the number of cases often exceeding those of Salmonellosis and Shigellosis [5,18].

This article is an open access article licensed under the terms of the Creative Commons Attribution License (http://creativecommons org/licenses/by/2.0) which permits unrestricted use, distribution and reproduction in any medium, provided the work is properly cited.
This increase, as well as the expanding spectrum of diseases caused by the organisms, necessitates a clearer understanding of the epidemiology and control of Campylobacteriosis.

The aim of this study was to establish the presence of Campylobacter in ground water (wells) and to determine the prevalence and distribution of Campylobacter species isolated from ground water.

\section{Materials and Methods}

Study Area: Sokoto is the capital of Sokoto State, Nigeria. The State is located to the extreme Northwest of Nigeria between longitudes $4^{\circ} 8^{\prime} \mathrm{E}$ and $6^{\circ} 54^{\prime} \mathrm{E}$ and between latitudes $12^{\circ} \mathrm{N}$ and $13^{\circ} 58^{\prime} \mathrm{N}$ [19]. Sokoto metropolis comprises of four local Government area (LGA) namely; Sokoto south, Sokoto north, Wamakko and Dange Shuni local government areas.

Collection of sample: A total of 74 water samples were collected from 15 wells in Sokoto metropolis (the wells that were samples were both government owned wells and private wells), over a period of four months from May to August 2011. The water samples were collected in the morning (between 10.00am and 11.30am) and $1 \mathrm{ml}$ of the water sample was added to sterile bijour bottles containing $9 \mathrm{mls}$ of Amies transport media (Oxiod, CM0425) and were transported to the laboratory immediately in ice-packed container for analysis.

I solation and identification of Campylobacter: The water samples contained in the pre-enrichment media 
Table-1. Percentage distribution of Campylobacter species isolated from wells in Sokoto metropolis

\begin{tabular}{lcc}
\hline Campylobacter $(\mathbf{C})$ species & Number positive & Percentage (\%) \\
\hline C. coli & 11 & $28.21 \%$ \\
C. hyointestinalis & 5 & $12.82 \%$ \\
C. jejuni & 23 & $58.97 \%$ \\
\hline
\end{tabular}

(Amies) were incubated at $42^{\circ} \mathrm{C}$ for 48 hours, after which a loopful of the pre-enrichment culture was plated onto modified Charcoal Cefaperazone Deoxycholate Agar (mCCDA) (Oxiod CM0739) and incubated at $42^{\circ} \mathrm{C}$ for 48 hours in a microaerophilic atmosphere generated by CampyGen system (Oxiod $\mathrm{Cn} 25)$. All suspected colonies were identified by Gram staining and biochemical test involving oxidase test, catalase test, hippurate hydrolysis and sensitivity to nalidixic acid and cephalothin. Organism was considered to be Campylobacter species if they were motile, catalase positive and oxidase positive [20,21].

The speciation of isolates were based on biochemical characterization involving hippurate hydrolysis (Sigma, Munich), susceptibility or resistance to nalidixic acid and cephalothin determined by standard diffusion techniques with $30 \mu \mathrm{g}$ discs (Oxiod) incubated in microaerophilic conditions at $37^{\circ} \mathrm{C}$ for 48 hours. Isolates that hydrolyses hippurate were identified as $C$. jejuni $(C$. jejuni is the only Campylobacter specie that hydrolyses hippurate). Isolates that were susceptible to nalidixic acid but resistant to cephalothin were identified as $C$. coli, and the isolates that were resistant to both nalidixic acid and cephalothin were identified as $C$. hyointestinalis.

\section{Results}

Out of the 74 water samples collected and analyzed, $39(52.70 \%)$ were positive for Campylobacter species. The Campylobacter species isolated from the water samples were $C$. jejuni $(58.97 \%)$, C. coli $(28.21 \%)$ and C. hyointestinalis $(12.82 \%)$. The most common Campylobacter species in this study was $C$. jejuni while $C$. hyointestinalis had the lowest isolation rate (Table-1).

\section{Discussion}

The presence of Campylobacter species in ground water has been established in this study. The result of this study indicates that the overall prevalence of Campylobacter from ground water in this study was $52.70 \%$. The prevalence rate in this study was higher than the rate reported by Akwuobu and Ofukwu [22] who observed a rate of $5.8 \%$ in well water samples in Makurdi, Benue State, Nigeria. The difference in the prevalence in this study compared to the other study may be due to the fact that the study area has the second largest livestock population in the country, having 3 million cattle, 3.85 million sheep, 4 million goats, 800,000 camels and various species of poultry including chickens guinea fowls, ducks and turkeys [23] and so more livestock congregate around wells to drink water and also to feed on grasses around the wells during which they defecate into the water [24]. It has been established that the natural habitat of Campylobacter spp. is the intestinal tract of warmblooded animals [25,26], and almost all the livestock in the study area are reported to carry the organism [2730]. The most frequently isolated Campylobacter species from wells in Sokoto metropolis was $C$. jejuni. This observation is in agreement with the reports that C. jejuni is the most common thermophilic Campylobacter species in water [24]. The isolation rate of $C$. coli was $28.21 \%$, these observation is in line with the report of Popowski et al. [24] on the basis that the isolation rate of $C$. coli in rivers is always lower than that of $C$. jejuni. The low isolation rate of $C$. hyointestinalis may be associated with the incubation temperature of $42^{\circ} \mathrm{C}$ which optimized the growth of thermophilic Campylobacters $(C$. jejuni and $C$. coli). However the use of CampyGen gas generating sachets may have further suppressed the growth of nonthermophilic Campylobacters like $C$. hyointestinalis, as it does not create a hydrogen enriched atmosphere which is required by the non-thermopilic Campylobacters [31]. The prevalence of Campylobacter species in wells in the study area is high; the potential of human infection through drinking water from these sources is also very high.

\section{Conclusion and recommendation}

This study has shown that Campylobacter organisms are present in wells in Sokoto, Sokoto State. The identification of these organisms in wells is of serious public health importance as untreated drinking water has been implicated as the cause of sporadic infections and outbreaks of Campylobacteriosis worldwide [32].

Based on the findings from this study and the public health implications of Campylobacter infection, the following recommendations are suggested:

* Government and individuals should intensify public health education on proper casing and covering of wells to avoid contamination by sewages and by fecal droppings of animals that gather around wells to drink water.

* Public enlightenment on the hazards involved in drinking untreated water from wells and

* The conventional treatment of domestic water supplies which can be accomplished by the addition of chlorine which is highly effective against certain Gram-negative bacteria like Campylobacter and enteric bacteria such as the coliform group.

\section{Authors' contribution}

All authors contributed equally. All authors read and 
approved the final manuscript.

\section{Acknowledgements}

My sincere gratitude goes to the staff of Veterinary public health laboratory and Veterinary anatomy laboratory for their time and technical guidance during the period of this work. My gratitude also goes to my sister Dr. Onyeka Ugboma and to my colleague Dr. Ifeanyi Agba and friend Mr. Mu'azu Baba Usman for their kind assistance during the period of this study.

\section{Competing interests}

Authors declare that they have no competing interest.

\section{References}

1. Chaveerach, P., Keuzenkamp, D.A., Urlings, H.A., Lipman, L.J. and van Knapen, F. (2002) In vitro study on the effect of organic acids on Campylobacter jejuni/coli populations in mixtures of water and feed. Int J Poul Sci, 81: 621-628.

2. Friedman, C.R., Hoekstra, R.M., Samuel, M., Marcus, R., Bender, J., Shiferaw, B. and Tauxe, R.B. (2004) Risk factors for sporadic Campylobacter infection in the United States: a case-control study in foodNet sites. Clin Infect Dis, 38 (suppl 3): S285-S296.

3. Ryan, K.J. and Ray, C.G. (editors) (2004) Sherris Medical Microbiology (4th ed.). McGraw Hill. pp. 378-80.

4. WHO. (2011) Campylobacter: Fact Sheet No. 255. http://www.who.int/campylobacter. Retrieved on 30-072012.

5. Adzitey Frederick and Nurul Huda, (2011) Campylobacter in Poultry: Incidences and possible Control Measures. Research Journal of Microbiology, 6: 182-192.

6. CDC. (2010) Campylobacter: Technical Fact Sheet. CDC Web site http://www.cdc.gov/ncidod/dbmd/ diseaseinfo/campylobacter_t.htm. Retrieved on 30-07-2012.

7. Halablab, M.A., Mohammed, K.A.S. and Miles, R.J. (2008) Growth and survival of Campylobacter pathogens in the presence of different metabolic inhibitors. Journal of Medical sciences, 8: 262-264.

8. Demborg, P., Olsen, K.E., Moller Nielson, E. and Guardabassi, L. (2004) Occurrence of Campylobacter jejuni in pets living with human patients infected with $C$. jejuni. $J$ Clin Microbiol, 42: 1363-1364.

9. Friedman, C.R., Neimann, J., Wegener, H.C. and Tauxe, R.V. (2001) Epidemiology of Campylobacter jejuni infections in the United States and other industrialized nations. In Campylobacter (I. Nachamkin and M.J. Blaser, eds). American Society for Microbiology Press, Washington, DC, 121-138.

10. Neimann, J., Engberg, J., Molbak, K. and Wegener, H.C. (2003) A case-control study of risk factors for sporadic Campylobacter infections in Demark. Epidemiol Infect, 130:353-366.

11. Minihan, D., Whyte, P., O'Mahony, M., Fanning, S., McGill, K. and Collins, J.D. (2004) Campylobacter spp. in Irish feedlot cattle: A longitudinal study involving pre-harvest and harvest phases of the food chain. J. Vet. Med. B 51:28-33.

12. Wolf, T.F., Duim, B., Geelen, S.P., Rigter, A., ThomsonCarter, F., Fleer, A. and Wagenaar, J.A. (2001) Neonatal sepsis by Campylobacter jejuni: genetically proven transmission from a household puppy. Clin Infect Dis, 32: E97-E99.

13. Government of West Australia, Department of Public Health. (2012) Campylobacter Fact Sheet. http://www.publichealth. wa.gov.au Retrieved on 30-07-2012.

14. Ashbolt, N.J. (2004) Microbial contamination of drinking water and disease outcomes in developing regions, Toxicology 198: 229-238.

15. Hanninen M.L., Haajanen H., Pummi T.,Wermundsen K., Katila M.L., Sarkkinen H.,Miettinen I. and Rautelin H.
(2003) Detection and typing of Campylobacter jejuni and Campylobacter coli and analysis of indicator organisms in three waterborne outbreaks in Finland, Appl. Environ. Microbiol. 69: 1391-1396.

16. Chin, James. (2000) Control of Communicable Diseases Manual. $17^{\text {th }}$ Edition. Washington, American Public Health association, 624p.

17. Galadima, A., Garba, Z.N., Leke, C., Almustapha, M.N. and Adam, I.K. (2011) Domestic water pollution among local communities in Nigeria, Causes and Consequences. Eur. $J$ SciRes.52(4): 592-603.

18. U.S Food and Drug Administration. (2012) BBB - Food borne Pathogenic Microorganisms and Natural Toxins Handbook; Campylobacter jejuni. http://www.fda.gov/ medlineplus/ency/article/000224.htm. Retrieved on 01-082012.

19. MOCIT. (2002) Guide to Sokoto State's Economic potentials. Commerce Department, Ministry of Commerec, Industry and Tourism, Sokoto State. Pp. 4-18.

20. Atabay, H. L., and Corry, J.E.L. (1997) The prevalence of Campylobacters and Arcobacters in Broiler chickens. J Appl Microbiol, 83: 619-626.

21. Coker, A.O. and Adefeso, A.O. (1994) The changing patterns of Campylobacter jejuni/coli in Lagos, Nigeria after ten years. East Afri Med J, 74: 437-440.

22. Akwuobu, C.A. and Ofukwu, R.A. (2007) Campylobacter jejuni in Duck faeces around Drinking Water Sources in Markudi, North-Central Nigeria:Public Health Implication. Tanzania Vet J, 27(1): 21-26.

23. Anon. (2008). Guide to Sokoto State's Economic potentials. Sokoto State Investment Promotion Commitee. Website: http://www.invest.showcase.comm.sokoto. Retrieved on 30-07-2012.

24. Popowski, J., Lekowska-Kochaniak, A. and Korsak, D. (1997) The incidence of heat tolerant Campylobacter in rivers and lakes of the Warsaw region. Roczniki Panstwowego Zakladu Higieni, 48: 253-262.

25. Altekruse, S.F., Hunt, J.M., Tollefson, L.K. and Madeen, J.M. (1994) Food and animal sources of human Campylobacter jejuni infection. J Am Vet Med Ass, 204(1): 57-61.

26. Rosef, O., Gondrosen, B., Kapperud, G. and Underdal, B. (1983) Isolation and characterization of Campylobacter jejuni and Campylobacter coli from domestic and wild mammals in Norway. Appl Env Microbiol,46: 855-859.

27. Salihu, M.D., Junaidu, A.U., Oboegbulem, S.I. and Egwu, G.O. (2009a) Prevalence and Biotypes of Campylobacter species isolated from sheep in Sokoto State. Int J Ani and Vet $A d v, 1$ (1): 6-9.

28. Salihu, M.D., Junaidu, A.U., Oboegbulem, S.I., Egwu, G.O., Tambuwal, F.M. and Yakubu, Y. (2009b) Prevalence of Campylobacter species in apparently healthy goats in Sokoto state (North western) Nigeria, Afri J Microbiol Research, 3(9) pp. 572-574.

29. Salihu, M.D., Junaidu, A.U., Oboegbulem, S.I., Egwu, G.O. and Magaji, A.A. (2009c) Isolation and Prevalence of Campylobacter species in cattle from Sokoto State, Nigeria. Vet Ital. 45 (4), 501-505.

30. Salihu, M.D., Junaidu, A.U. and Oboegbulum, S.I., Egwu, G.O., Magaji, A.A., Abubakar, M.B. and Ogbole, A. (2010) Prevalence of Campylobacter Species in Nigerian indigenous chicken in Sokoto State, Northwestern, Nigeria. Internet J Vet Med, 7 (1).

31. Workman, N.S., Mathison, E.G. and Lavoie, C.M. (2005) Pet dogs and chicken meat as Reservoir of Campylobacter species in Barbados. J Clin Microbiol, 43(6): 2642-2650.

32. Koenraad, P.M.F.J., Rombouts, F.M. and Notermans, S.H.W., (1997) Epidemiological aspects of thermophilic Campylobacter in water-related environment: A Review. Water Env Research, 69: 52-63. 